\title{
Forekomst av villet egenskade estimert ved data fra Norsk pasientregister
}

\author{
Av Ping Qin, Lisa V. Burrell, Anne S. Bøe og Lars Mehlum
}

Denne artikkelen er en revidert versjon av artikkelen publisert i PLoS ONE, 2020.

\section{SAMMENDRAG}

Pasientregistre er verdifulle kilder til å identifisere villet egenskade på befolkningsnivå, men vi mangler innsikt i hvordan vi best benytter denne komplekse datakilden. I denne studien har vi benyttet data fra Norsk pasientregister for å identifisere tilfeller og estimere forekomsten av medisinsk behandlet villet egenskade ved hjelp av kombinasjoner av diagnostiske koder. Dataene av alle akutt behandlingskontakter grunnet ytre årsaker ved somatiske sykehus 2008-2013 ble satt sammen og videre prosessert gjennom en flertrinns analytisk strategi. Gjennom en grundig undersøkelse av 13533 registrerte tilfellene av villet egenskade utarbeidet vi et system av diagnosekodekombinasjoner for å identifisere alle sannsynlige tilfeller av villet egenskade. Denne prosessen resulterte i totalt 38433 tilfeller (justerte tilfeller) - et tall som er 2,84 ganger høyere enn det registrerte antallet tilfeller av villet egenskade i studieperioden. Disse justerte tilfellene tilsvarer rundt 6400 tilfeller hos 5100 personer per år, hvilket svarer til en årlig kumulativ insidensrate på 121,0 per 100000 personer eldre enn 10 år. Studien viser at villet egenskade behandlet ved norske sykehus sannsynligvis er et vesentlig mer omfattende problem enn antatt og at data fra Norsk pasientregister er en viktig kilde for innhenting av kunnskap om karakteristikker av slike skader og om utviklingen av forekomst over tid.

\section{ABSTRACT}

Patient registry is a valuable source for identification of deliberate self-harm (DSH) incidents on a population basis; however, little research has provided sufficient insights to inform best utilization of this complicated data source. In this study using data from the Norwegian Patient Register we delineated a diagnostic coding system to identify incidents of medically treated DSH and to estimate its incidence rate in the population. Data on all emergent contacts for somatic treatment due to external causes during 2008-2013 were retrieved and further processed following a multi-step analytic strategy. Through carefully analysis of 13533 incidents with a recorded diagnosis of DSH, we devised a diagnostic coding system to identify all possible DSH incidents. This yielded a total of 38433 incidents to be considered as likely incidents of DSH (adjusted incidents) - a number that is 2.84 times higher than that of the recorded DSH incidents during the study period. These adjusted incidents imply about 6400 DSH incidents from 5100 persons per year and correspond to a yearly cumulative incidence rate of 121.0 per 100000 population over 10 years old. The study underscores that DSH being treated in Norwegian hospitals is a more prominent problem than thought and that Norwegian Patient Registry is an important source for knowledge on the characteristics of DSH incidents and the development of its incidence over time. 


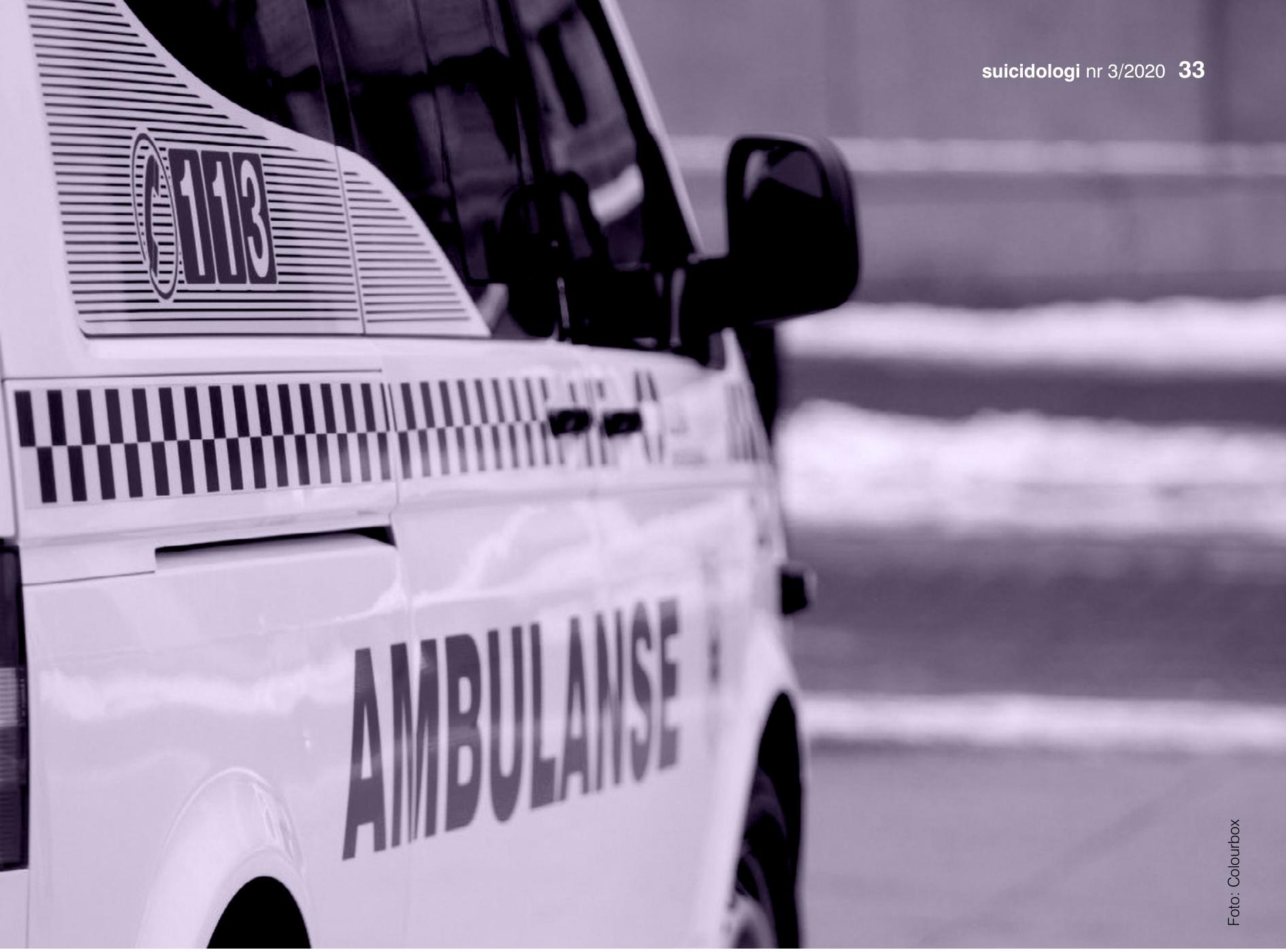

\section{Introduksjon}

Villet egenskade er et omfattende folkehelseproblem i Norge og mange andre deler av verden, men korrekt identifisering av tilfeller av villet egenskade og rapportering av forekomst på et nasjonalt nivå har vist seg å være vanskelig (World Health Organization, 2014). Villet egenskade er en handling med selvpåført skade i form av forgiftning og fysisk skade som ikke ender med døden. Mangelen på systematisk registrering av villet egenskade skaper et betydelig kunnskapsgap i vår forståelse av ikke-dødelig villet egenskade. For å undersøke tilfeller av villet egenskade i befolkningen har hovedsakelig to metoder blitt benyttet. Den forste metoden omfatter selvrapportering av villet egenskade $i$ et bestemt tidsrom giennom spørreundersøkelser i et representativt utvalg av befolkningen. Denne metoden har den fordel at den også favner personer som ikke har vært i kontakt med behandlingsapparatet, men har samtidig de samme feil og mangler som spørreskjemaundersøkelser flest, slik som mulig lav reliabilitet, seleksjonsskjevhet og informasjonsskjevhet (World Health Organization, 2014; Muehlenkamp et al., 2012). Den andre metoden for å undersøke tilfeller av villet egenskade innebærer å hente ut data fra medisinske registre om pasienter som har vært behandlet for villet egenskade i helsevesenet. Selv om denne metoden bare vil samle inn de tilfellene av villet egenskade som er alvorlige nok til å kreve medisinsk behandling (World Health Organization, 2014; Erlangsen et al., 2018), utgiør denne tilnærmingen den beste muligheten vi har til å oppnå reliable og presise data om slike former for villet egenskade på et befolkningsnivå.

Forskningsmessig bruk av pasientregistre for å identifisere tilfeller av villet egenskade i en stor populasion har vært $₫$ kende de siste årene. For eksempel har villet egenskade eller selvmordsforsøk blitt studert ved å benytte The Veteran Healthcare System Database i USA (Deka et al., 2018), The Multicentre Self-Harm Database i Storbritannia (Kapur et al., 2015), nasjonale pasientregistre i Sverige og Danmark (Qin et al., 2009; Reuter Morthorst et al., 2016; Runeson et al., 2010), og The National Self-Harm Registry i Irland (Perry et al., 2012). Så vidt vi vet har ingen tidligere studier gitt en detaljert forklaring på hvordan tilfeller av villet egenskade ble identifisert fra de medisinske registrene.

I denne studien benytter vi data fra Norsk pasientregister (Helsedirektoratet, 2019) for å profilere registrerte tilfeller av villet egenskade (X6n), samt for å utvikle en datadrevet diagnostisk algoritme for å identifisere alle sannsynlige tilfeller av villet egenskade fra pasientregisteret. Deretter vil vi profilere generelle karakteristikker for de registrerte og sannsynlige tilfellene av villet egenskade og estimere insidensraten for all villet egenskade behandlet på sykehus i den norske befolkningen (Qin \& Mehlum, 2020). 


\section{Metodisk tilnærming \\ Datakilder}

Den primære datakilden var Norsk pasientregister (NPR) som omfatter data på et individuelt nivå for hele den norske befolkningen siden 2008 (Helsedirektoratet, 2019). Registeret inneholder data fra kontakt med både somatisk og psykiatrisk spesialisthelsetjeneste. For hver kontakt eller behandling registreres dato for kontakten, primær- og sekundærdiagnoser, type kontakt, behandlingens hastegrad, samt andre detaljer som hvorvidt behandlingen var planlagt eller akutt og enheten som giennomforte behandlingen. Diagnoser for sykdom følger den norske utgaven av The International Classification of Diseases, version 10 (ICD-10)

(Direktoratet for e-helse, 2018). For behandlingskontakt som skyldes ytre årsaker, kan en supplerende klassifisering kalt E-koder benyttes for å beskrive tilstanden ytterligere, eksempelvis tilleggskoden «X6n» som refererer til villet egenskade. NPR gir oss mulighet til å identifisere personer som har vært i kontakt med spesialisthelsetjenesten for behandling grunnet selvpåført skade, ulykker, skader påført av andre og lignende.

Andre datakilder som vi benyttet inkluderte Folkeregisteret og FD-Trygd-databasen fra Statistisk sentralbyrå (Statistisk sentralbyrå, 2020a; 2020b). Disse registrene gir tilgang til informasjon om kjønn,

Figur 1. Prosessen for å selektere tilfeller av skader og forgiftninger behandlet i spesialisthelsetjenesten i Norge mellom 2008 og 2013.

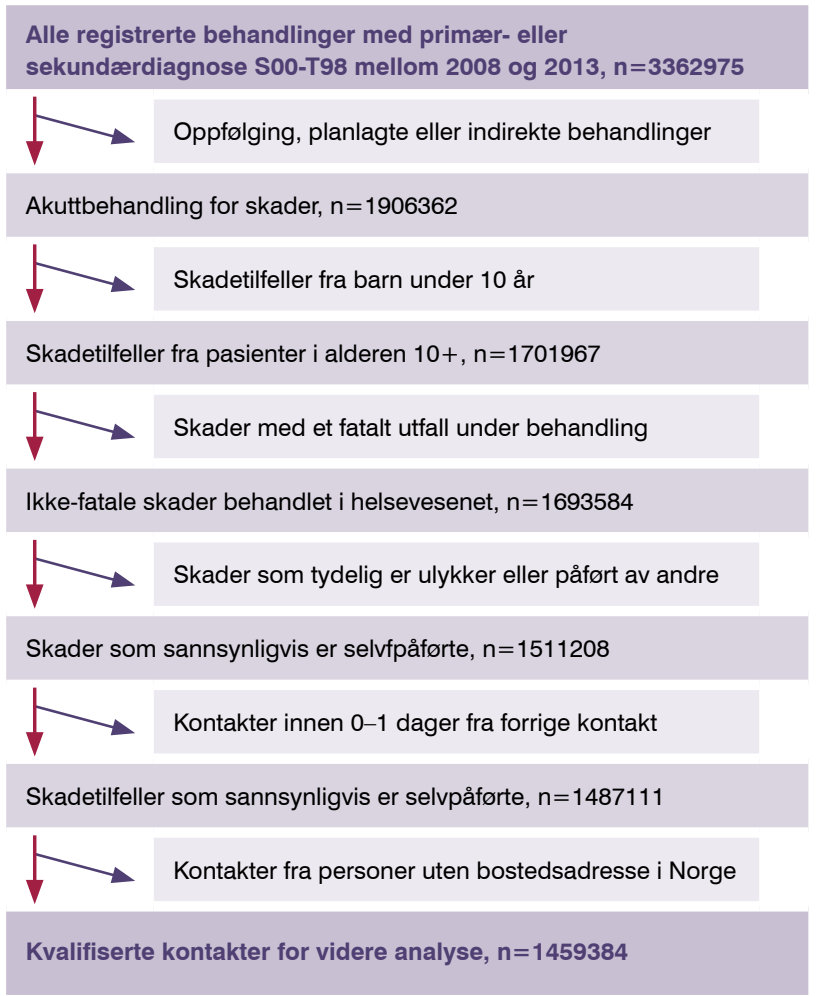

fødselsdato og bosted, samt personnummer som muliggiør sammenkobling av informasjon på tvers av registrene. Informasion om størrelsen på den norske befolkningen, fordelt på kjønn og aldersgrupper, fra første januar hvert år i studieperioden ble hentet fra Statistisk sentralbyrås hjemmeside (Statistisk sentralbyrå, (2019).

\section{Prosedyre for datautvinning}

Vi fikk tilgang til alle pasientkontakter i NPR for behandlinger grunnet ytre årsaker, det vil si forgiftning eller skade kodet med Soo-T98 i ICD-10 som primæreller sekundærdiagnose, fra og med 2008 til og med 2013 (N=3 502707 ). For disse registrerte kontaktene utførte vi en begrenset datautvinningsprosess, som vist i Figur 1. Først utelukket vi kontakter som var i form av møtevirksomhet, oppfølgingsbehandling, rehabilitering, indirekte pasientkontakt og kontakter som ikke var i akuttbehandling. For de gienstående kontaktene fjernet vi alle kontakter med barn under 10 år siden forgiftning eller ulykker hos så små barn sjelden er bevisst selvpåført. Vi utelukket så forgiftninger eller ulykker som resulterte i dødsfall, og beholdt kun ikke-fatale tilfeller for videre vurdering. Deretter fjernet vi alle rapporterte tilfeller av ulykker, krigsrelaterte skader, sekundære medisinske skader, skader påført av andre eller skader påført av årsaker i det omgivende miliø, det vil si tilfeller kodet med Vo-X5, X8n, Y3n, Y4n-Y86 eller Y88-Y98 som primær- eller sekundærdiagnose uten tillegg av en X6n, X6 eller Y87 kode. Videre ekskluderte vi episoder som var registrert o-1 dager etter den forrige episoden siden disse høyst sannsynlig utgiorde dobbelrapportering av samme hendelse av ansatte fra ulike kliniske avdelinger eller fra overføring mellom avdelinger. For de få tilfellene der en episode var rapportert flere ganger på samme dag, ble tilfellet med en komorbid diagnose med villet egenskade (kodet med X6n, X6 eller Y87) prioritert og inkludert i databasen for videre studier; ellers ble det første tilfellet fra en alfabetisk liste over primærdiagnoser beholdt. Til slutt ekskluderte vi tilfeller der personene som mottok behandlingen ikke hadde en permanent bostedsadresse i Norge på tidspunktet for behandlingen, slik at kun tilfeller med aktivt bosatte i Norge ble beholdt.

Etter å ha giennomgått den ovennevnte prosedyren ble totalt 1459384 kontakter vurdert som kvalifiserte tilfeller av ikke-fatale skader eller forgiftninger hos innbyggere over 10 år som fikk akuttbehandling i spesialisthelsetjenesten i Norge, der skaden eller forgiftningen antageligvis var selvpåført. Disse kvalifiserte tilfellene utgiorde grunnlaget av pasientkontakter for identifisering av tilfeller av villet egenskade i denne studien.

\section{Definisjon av variabler}

Basert på informasjonen hentet fra NPR, konstruerte vi en rekke variabler som ble benyttet i analysene. Kliniske diagnoser av interesse ble definert og 
kategorisert i overenstemmelse med den norske utgaven av ICD-10 (Direktoratet for e-helse, 2018).

1. Registrert villet egenskade: Registrert villet egenskade ble definert som å ha en X6n eller Y87 kode som primæreller sekundærdiagnose i sammenheng med forgiftningen eller skaden som ble behandlet. Denne diagnosen er rapportert av førstelinjebehandlere, og er vanligvis basert på informasjon fra pasienten selv eller komparenter. Kodene for villet egenskade er ofte underregistrert og gis med få unntak som en sekundærdiagnose.

2. Form for skade: Gruppert i følgende 6 kategorier 1) forgiftning med medikamenter $\left(\mathrm{G}_{1}\right), 2$ ) forgiftning med andre stoffer $\left(\mathrm{G}_{2}\right), 3$ ) skader på underarmer, hender, håndledd eller overarmer $\left.\left(\mathrm{G}_{3}\right), 4\right)$ skader på andre spesifikke deler av kroppen $\left(\mathrm{G}_{4}\right), 5$ ) skader grunnet kvelning, fremmedlegemer i kroppen, drukning, brenning og lignende $\left(G_{5}\right), 6$ ) andre skader (G6). De eksakte ICD-10 kodene som ble inkludert i hver kategori er presentert i Tabell 1.

3. Komorbiditet med psykisk lidelse: Definert som ICD-10 kodene Fo-F9 som primær- eller sekundærdiagnose. For hvert tilfelle hentet vi ut informasion om mulige psykiatriske diagnoser og analyserte diagnosene i konteksten av typen skade.

\section{Statistiske analyser}

I denne studien fulgte vi følgende flertrinnsstrategi for å analysere dataene. Først undersøkte vi alle tilfeller med en registrert diagnose av villet egenskade for å studere fordelingen av skader eller medisinske forhold som ofte ble rapportert sammen med denne komorbide diagnosen. I det andre trinnet, basert på funnene fra første analysesteg og vår kunnskap om villet egenskade, utviklet vi en datadrevet diagnostisk algoritme for koding, som så ble benyttet til å identifisere sannsynlige tilfeller av villet egenskade fra de kvalifiserte tilfellene. Utvelgelsen var hierarkisk og prioritet ble gitt til tilfeller registrert med en diagnose med villet egenskade, psykiatrisk komorbiditet og typen skade. De registrerte og sannsynlige tilfellene utgiør til sammen de justerte tilfellene av villet egenskade. I trinn tre undersøkte vi generelle og kliniske karakteristika av de justerte tilfellene av villet egenskade identifisert giennom det foreslåtte kodingssystemet, og sammenlignet med de registrerte tilfellene av villet egenskade ved hjelp av kjikvadrattester. Til slutt estimerte vi den årlige forekomsten av villet egenskade og det tilhørende 95\% konfidensintervallet i den norske befolkningen i løpet av studieperioden. Alle analyser ble giennomført ved bruk av SAS/STAT version 9.4 av SAS systemet for Windows. Copyright (C) [2019] SAS Institute Inc., Cary, NC, USA.

\section{Etiske vurderinger}

Studien var godkjent av Regional komite for medisinsk og helsefaglig forskningsetikk Sør-Øst (2013/1620/REK Sør-Øst) og eierne av de relevante registrene.

\section{Resultater \\ Undersøkelse av registrerte tilfeller av villet egenskade}

Fra 1459384 tilfeller av akuttbehandling for skader og forgiftninger i løpet av den 6 år lange studieperioden, identifiserte vi 13533 tilfeller (o,93\%) som hadde en registrert diagnose av villet egenskade: 4175 tilfeller menn og 9358 kvinner. Tabell 1 viser fordelingen av primærdiagnosene til de registrerte tilfellene av villet egenskade, fordelt på typen skade.

Forgiftning med medikamenter (G1) var den vanligste primærårsaken til en behandlingskontakt registrert med villet egenskade, og utgiorde $73,2 \%$ av disse tilfellene. Skader på underarm, hender, overarmer og andre spesifikke deler av kroppen ( $\left.\mathrm{G}_{3}-\mathrm{G}_{4}\right)$, samt skader grunnet kvelning, fremmedlegemer i kroppen, drukning og brenning ( $\mathrm{G}_{5}$ ) utgiorde primærdiagnosene i til sammen $8,5 \%$ av de registrerte tilfellene av villet egenskade. Selv om akutt skade var involvert i alle tilfellene registrert med villet egenskade på grunn av studiens inklusionskriterier, utgiorde somatisk sykdom (G8) primærdiagnosen i 4,3\% av tilfellene og psykiske lidelser (G9) primærdiagnosen i 6,9\% av tilfellene.

Videre var en komorbid diagnose med psykisk lidelse registrert i 58,3\% av alle tilfellene registrert med villet egenskade, noe som indikerer viktigheten av psykiatrisk komorbiditet i rapporteringen av skader eller forgiftning som villet egenskade av førstelinjearbeidere i helsevesenet.

\section{Identifisering av justerte tilfeller av villet egenskade}

Basert på skadetilfeller registrert med en diagnose med villet egenskade, samt vår kunnskap om villet egenskade og erfaringer fra andre land (Helweg-Larsen et al., 2006), utarbeidet vi en datadrevet diagnostisk algoritme for å identifisere alle sannsynlige tilfeller av villet egenskade fra de kvalifiserte kontaktene. Vi utførte en 4-trinns hierarkisk vurdering som forklart her: 1) alle tilfeller registrert med villet egenskade som primær- eller sekundærdiagnose (13 533 inkluderte tilfeller), 2) tilfeller med primærdiagnose oppført i G1-G5 og sekundærdiagnose med psykisk lidelse (9 501 inkluderte tilfeller), 3) tilfeller med sekundærdiagnose oppført i G1-G5 og primær- eller sekundærdiagnose med psykisk lidelse (4 813 inkluderte tilfeller), 4) tilfeller med primær- eller sekundærdiagnose med forgiftning med medikamenter (G1) som ikke dekkes av tidligere steg (10 586 inkluderte tilfeller). Totalt ble 38433 tilfeller vurdert som justerte tilfeller av villet egenskade som mottok medisinsk behandling på sykehus i 6-årsperioden fra 2008 til 2013. Tallet for justerte tilfeller av villet egenskade er dermed 2,84 ganger høyere enn tallet for tilfeller som er registrert med villet egenskade.

Tabell 1 viser også de justerte tilfellene av villet egenskade fordelt på primærdiagnose, tilstedeværelsen av registrert villet egenskade og psykiatrisk komorbiditet. Fordelingen av primærdiagnosene til de justerte tilfellene av villet egenskade var sammenlignbar med 


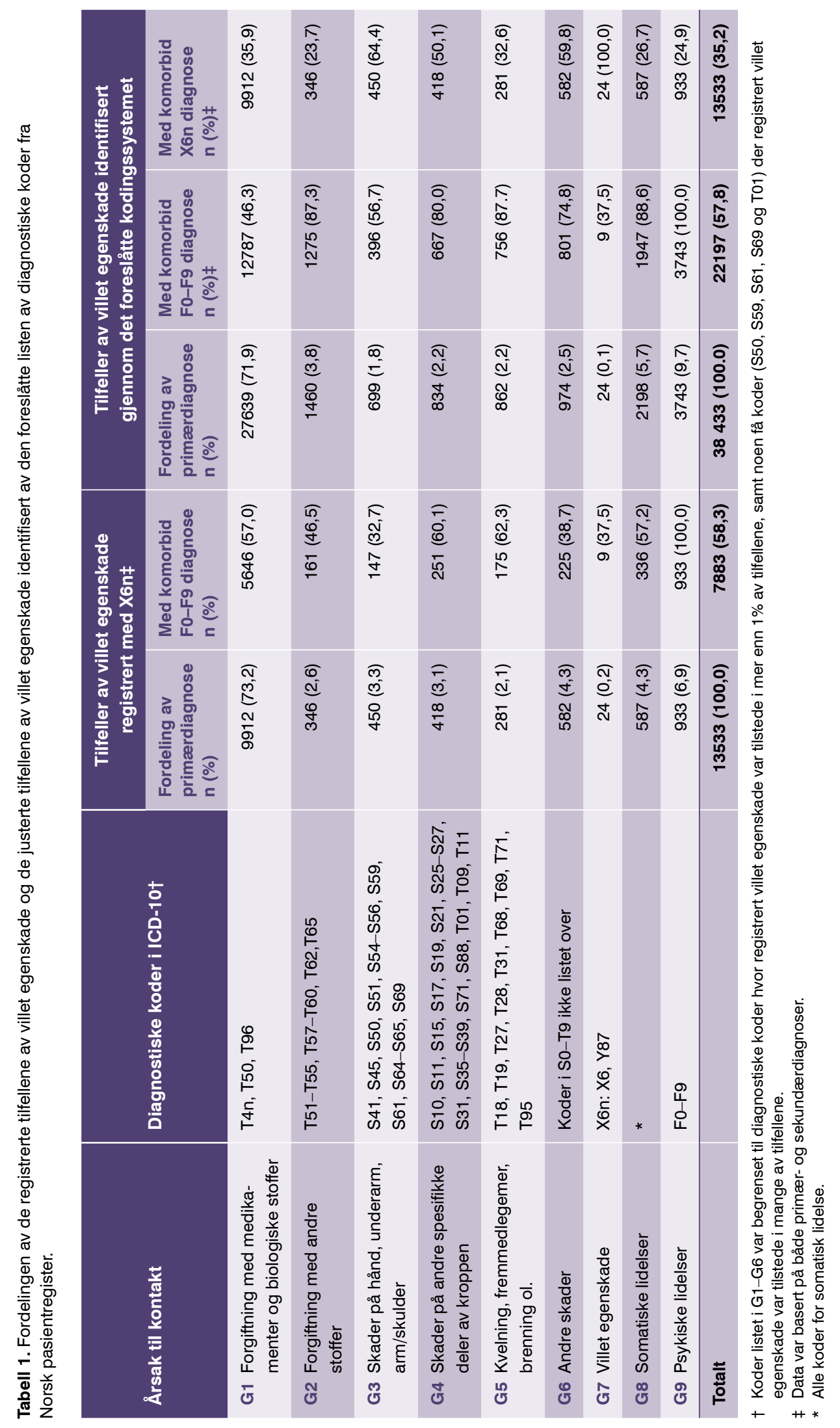


Tabell 2. Generelle karakteristika ved de 13533 tilfellene av registrert villet egenskade og de 38433 tilfellene av villet egenskade identifisert i kodingssystemet.

\begin{tabular}{|c|c|c|c|c|c|}
\hline \multirow{2}{*}{ Variabel } & \multicolumn{2}{|c|}{$\begin{array}{l}\text { Registrert villet egenskade } \\
\qquad N=13533\end{array}$} & \multicolumn{2}{|c|}{$\begin{array}{l}\text { Justert villet egenskade } \\
\qquad \mathrm{N}=\mathbf{3 8 4 3 3}\end{array}$} & \multirow[t]{2}{*}{$\begin{array}{l}\text { Test av } \\
\text { forskjell }\end{array}$} \\
\hline & N & $\%$ & $\mathbf{N}$ & $\%$ & \\
\hline \multicolumn{5}{|l|}{ Kalenderår } & \multirow{7}{*}{$\begin{array}{l}\chi^{2}=39,3 \\
p<0,001\end{array}$} \\
\hline 2008 & 2183 & 16,1 & 6479 & 16,9 & \\
\hline 2009 & 2109 & 15,6 & 6352 & 16,5 & \\
\hline 2010 & 2196 & 16,2 & 6193 & 16,1 & \\
\hline 2011 & 2261 & 16,7 & 6431 & 16,7 & \\
\hline 2012 & 2325 & 17,2 & 6489 & 16,9 & \\
\hline 2013 & 2459 & 18,2 & 6489 & 16,9 & \\
\hline \multicolumn{5}{|l|}{ Kjønn } & \multirow{3}{*}{$\begin{array}{l}x^{2}=646,7 \\
p<0,001\end{array}$} \\
\hline Kvinne & 9358 & 69,1 & 23271 & 60,5 & \\
\hline Mann & 4175 & 30,9 & 15162 & 39,5 & \\
\hline \multicolumn{5}{|l|}{ Aldersgruppe } & \multirow{7}{*}{$\begin{array}{l}\chi^{2}=998,2 \\
p<0,001\end{array}$} \\
\hline 10-19 år & 2305 & 17,0 & 5277 & 13,7 & \\
\hline 20-34 år & 5145 & 38,0 & 13405 & 34,9 & \\
\hline 35-49 år & 3527 & 26,1 & 9799 & 25,5 & \\
\hline 50-64 år & 1877 & 13,9 & 5777 & 15,0 & \\
\hline 65-79 år & 520 & 3,8 & 2277 & 5,9 & \\
\hline $80+$ år & 159 & 1,2 & 1898 & 4,9 & \\
\hline \multicolumn{5}{|l|}{ Typen skade* } & \\
\hline Forgiftning & 11698 & 86,4 & 34152 & 88,9 & \multirow{3}{*}{$\begin{array}{l}x^{2}=123,6 \\
p<0,001\end{array}$} \\
\hline Med medikamenter (T4n-T50, T96) & 11310 & 83,6 & 32026 & 83,3 & \\
\hline Med andre stoffer (T51-T65, T97) & 682 & 5,0 & 2867 & 7,5 & \\
\hline $\begin{array}{l}\text { Skader på en spesifikk } \\
\text { del av kroppen }\end{array}$ & 2182 & 16,1 & 5264 & 13,7 & \multirow{5}{*}{$\begin{array}{l}x^{2}=104,1 \\
p<0,001\end{array}$} \\
\hline Hodet (S00-S09, T90) & 281 & 2,1 & 532 & 1,4 & \\
\hline $\begin{array}{l}\text { Hender, underarmer, armer eller skuldre } \\
(\mathrm{S} 40-\mathrm{S} 69, \mathrm{~T} 91, \mathrm{~T} 92)\end{array}$ & 745 & $5, .5$ & 1519 & 4,0 & \\
\hline $\begin{array}{l}\text { Andre deler av kroppen } \\
\text { (S10-S39, S70-T14, T93, T94) }\end{array}$ & 867 & 6,4 & 1932 & 5,0 & \\
\hline $\begin{array}{l}\text { Kvelning, fremmedlegemer, drukning, brenning ol. } \\
\text { (T15-T35, T66-T78, T95) }\end{array}$ & 474 & 3,5 & 1712 & 4,5 & \\
\hline $\begin{array}{l}\text { Skader eller forgiftning som involverer } \\
\text { diagnostiske koder oppført i G1-G5 }\end{array}$ & 13001 & 96,1 & 37901 & 98,6 & $\begin{array}{l}\chi^{2}=992,6 \\
p<0,001\end{array}$ \\
\hline
\end{tabular}

* Både primær- og sekundærdiagnoser ble vurdert når vi undersøkte typen skade involvert, og derfor er ikke fordelingen på tvers av kategorier gjensidig utelukkende. 
fordelingen til de registrerte tilfellene av villet egenskade, der forgiftning med medikamenter utgiorde majoriteten. Det var derimot noen merkbare unntak $\left(\chi^{2}=544,7, p<0,001\right)$. De justerte tilfellene av villet egenskade omfattet noe færre skader $\left(G_{3}-G_{5}\right)$, men relativt flere med psykiske lidelser (G9) som primærdiagnose. Forgiftning (G1 og G2) utgiorde $75,7 \%$ av de justerte tilfellene av villet egenskade, inkludert 71,9\% med medikamenter og 3,8\% med andre stoffer, mens somatisk sykdom (G8) utgiorde primærdiagnosen i $5,7 \%$ av de justerte tilfellene av villet egenskade.

Videre var en komorbid diagnose med psykisk lidelse registrert i 57,8\% av de justerte tilfellene av villet egenskade, med en relativt lav andel blant forgiftning med medikamenter (G1, 46,3\%) og skader på underarm, hender og armer $\left(\mathrm{G}_{3}, 56,7 \%\right)$, og en høy andel blant skader på andre deler av kroppen ( $\left.\mathrm{G}_{4}, 80,0 \%\right)$, skader grunnet kvelning, fremmedlegemer, drukning, brenning og hopp fra høyder ( $\mathrm{G}_{5}, 87,7 \%$ ) og forgiftning med andre stoffer ( $\left.\mathrm{G}_{2}, 87.3 \%\right)$. En X6n kode var registrert i $35,2 \%$ av de justerte tilfellene av villet egenskade. Denne tilleggsdiagnosen ble hyppigst registrert for skader på underarmer, hender og armer $\left(\mathrm{G}_{3}, 64,4 \%\right)$, og minst hyppig registrert for forgiftning med andre stoffer (G2, 23,7\%) og tilfeller der somatisk eller psykisk lidelse utgjorde primærdiagnosen. Psykisk lidelse var generelt like vanlig blant de justerte og de registrerte tilfellene av

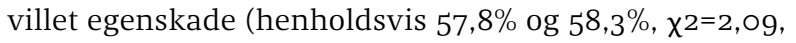
$\mathrm{p}=\mathrm{o}, 15)$.

\section{Noen karakteristika ved tilfellene av villet egenskade identifisert gjennom kodingssystemet}

Ved å følge det foreslåtte kodingssystemet identifiserte vi om lag 6400 tilfeller av villet egenskade fra ca. 5130 unike personer som ble behandlet i spesialisthelsetjenesten hvert år, med små variasjoner mellom de ulike årene i studieperioden (Tabell 2). Vi ser tydelig at de justerte tilfellene av villet egenskade fanget opp flere tilfeller i de første årene av studieperioden, da diagnosen for villet egenskade var mindre brukt ( $\chi_{2}^{2}=39,3$, $\mathrm{p}<0,001)$.

Selv om både registrert og justert villet egenskade var mer vanlig blant kvinner enn menn, var 39,5\% av de justerte tilfellene blant menn, noe som er signifikant høyere enn blant de registrerte tilfellene av villet egenskade $(30,9 \%, \mathrm{p}<0,01)$. Samtidig inkluderte de justerte tilfellene relativt flere tilfeller fra voksne i høy alder $(\mathrm{p}<0,01)$. For eksempel utgjorde villet egenskade blant personer over 64 år kun 5,0\% blant de registrerte tilfellene, mens denne andelen økte til 10,8\% blant de justerte tilfellene. Allikevel var flesteparten av de justerte tilfellene av villet egenskade blant ungdom og unge voksne.

I giennomsnitt identifiserte vi 3880 tilfeller blant kvinner og 2530 tilfeller blant menn av justert villet egenskade som ble behandlet i spesialisthelsetjenesten hvert år. Dette tilsvarte en ratio mellom kvinner og menn på 1,53 i løpet av studieperioden, men kjønnsfordelingen varierte betydelig med alder. Som vist

Figur 2. Kjønns- og aldersfordeling av tilfeller av villet egenskade identifisert fra de foreslåtte kodene fra Norsk pasientregister 2008 til 2013.

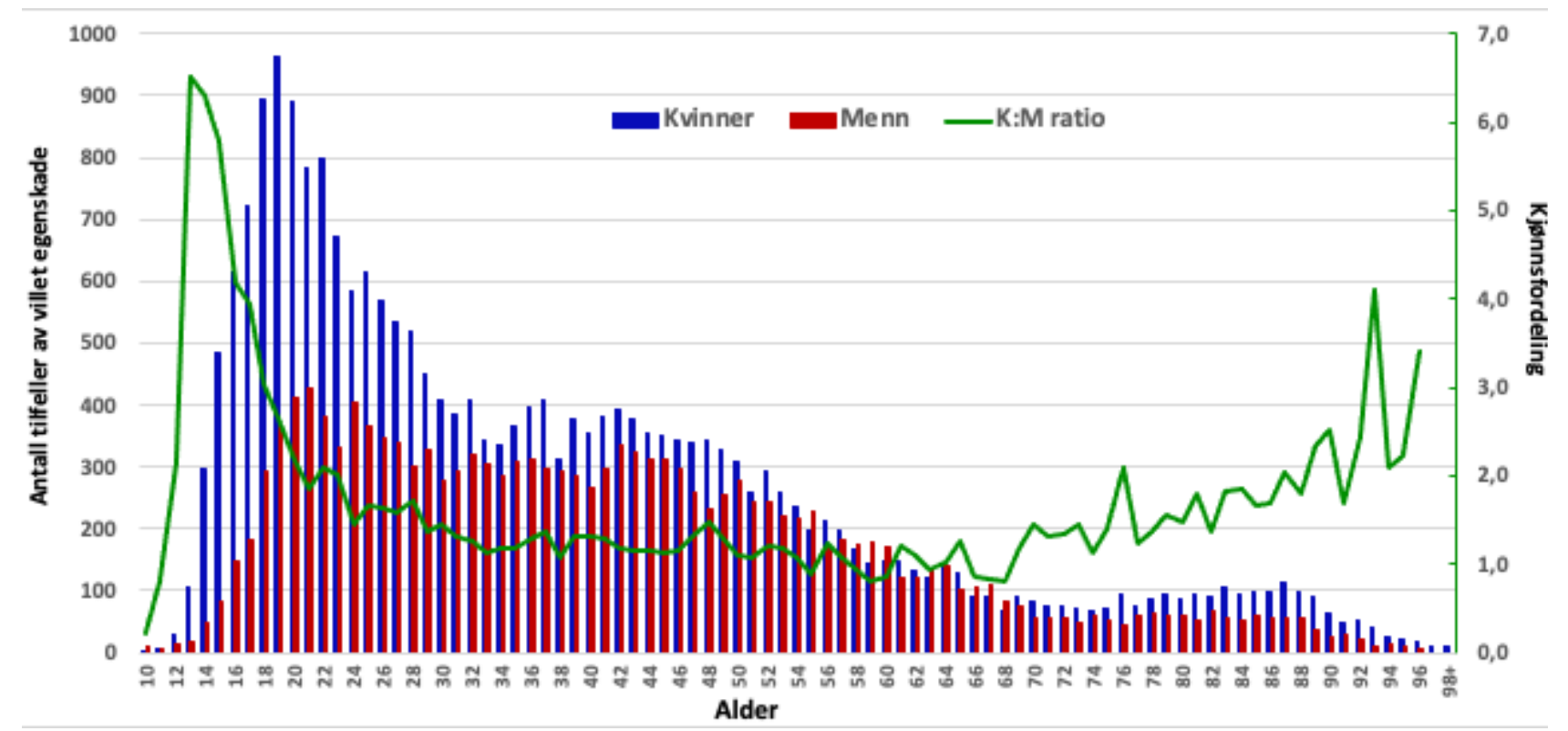


i Figur 2 økte tilfellene av justert villet egenskade kraftig fra tidlig ungdomstid til ung voksen alder, og nådde toppen i 19-20-årene. Denne aldersutviklingen var spesielt synlig blant unge kvinner, med en kraftig økning av villet egenskade blant jenter i alderen 13-16 år og en kjønnsfordeling mellom kvinner og menn på over 6:1. Mens de justerte tilfellene av villet egenskade var mer vanlig blant kvinner enn menn i de fleste aldersgrupper, observerte vi en omvendt kjønnsfordeling blant middelaldrende voksne i alderen 50-64 år.

Tabell 2 viser også fordelingen av typer skader diagnostisert som enten primær- eller sekundærdiagnose i de justerte tilfellene av villet egenskade. I alt $88,9 \%$ av de justerte tilfellene bestod av overdose med medikamenter $(83,3 \%)$ og/eller forgiftning med andre stoffer (7,5\%). Skader på ulike deler av kroppen hadde skjedd i $13,7 \%$ av de justerte tilfellene av villet egenskade, og skader på hender, underarmer og armer var involvert i $4,0 \%$ av disse tilfellene. Det er tydelig at de justerte tilfellene fanget opp relativt flere hendelser som involverte forgiftning, spesielt med andre stoffer enn medikamenter, men færre hendelser som involverte skader sammenlignet med de registrerte tilfellene av villet egenskade. Til sammen involverte $98,6 \%$ av de justerte tilfellene av villet egenskade en form for skade der de diagnostiske kodene tilhørte gruppene $\mathrm{G}_{1}-\mathrm{G}_{5}$ - en signifikant større andel enn de $96,1 \%$ blant de registrerte tilfellene av villet egenskade $(\mathrm{p}<0,001)$.

\section{Kumulativ insidens (insidensrate) av villet egenskade i den norske befolkningen}

Ifølge det foreslåtte diagnostiske systemet mottok i giennomsnitt 5130 unike personer (2 930 kvinner og 2200 menn) akutt somatisk behandling grunnet villet egenskade hvert år i studieperioden. Dette tilsvarer en årlig kumulativ insidensrate på 121,o (95\% KI: 113,4$128,2)$ per 100 ooo mennesker over 10 år, og en rate på $133,4 / 100000$ (95\% KI: 121,7-145,1/100 o00) for kvinner og 108,6/100 o०o (100,6-116,6/100 ooo) for menn.

Som vist i Tabell 3 varierte insidensraten betraktelig mellom ulike aldersgrupper og kiønn, med to klare topper - én blant unge og én blant eldre voksne. For de unge var den kumulative insidensraten høyest for tenåringsjenter i alderen 15-19 år (296,1/100 ooo) og unge kvinner og menn i alderen 20-24 år (henholdsvis $282,5 / 100$ ooo og 178,8/100 000). Enda insidensraten for villet egenskade var relativt lav blant voksne i 30-, 40- og 50-årene, var raten lavest blant mennesker mellom 65 og 74 år, for deretter å øke kraftig med økt alder blant eldre av begge kjønn.

\section{Diskusjon}

Validiteten til det foreslåtte kodingssystemet for identifisering av tilfeller av villet egenskade

Pasientregistre for medisinsk behandling utgiør en verdifull informasjonskilde for å studere villet egenskade forutsatt at vi giennomfører forskning som validerer registrenes evne til å identifisere tilfeller av

Tabell 3. Estimerte insidensrater av villet egenskade fordelt på kjønn og aldersgruppe i den norske befolkningen fra 2008 til 2013 (per 100000 mennesker).
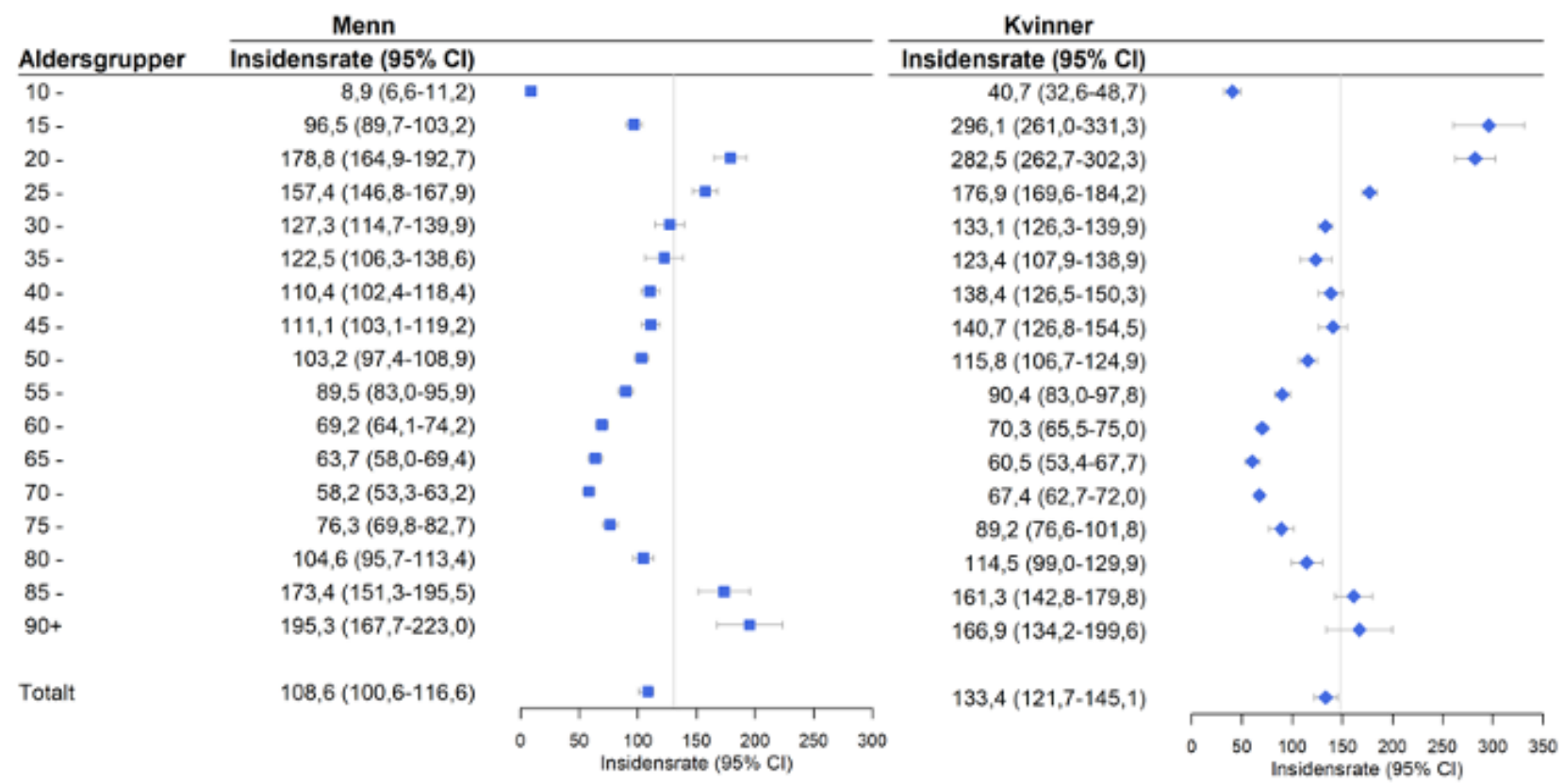
villet egenskade. I denne studien var vi ikke i stand til å benytte typiske metoder for validering av medisinske diagnoser giennom tilleggsinformasjon fra ytre kilder som kan danne et målbart estimat for validiteten til vårt foreslåtte diagnostiske system (for å beregne positiv prediktiv verdi, spesifisitet og sensitivitet) (Helweg-Larsen et al., 2006). I stedet analyserte vi karakteristikker ved skadetilfeller registrert med villet egenskade i kombinasjon med vår kunnskap om villet egenskade og utviklet en datadrevet diagnostisk algoritme for koding som kan benyttes til å identifisere sannsynlige tilfeller av villet egenskade fra Norsk pasientregister. I senere år har utviklingen av interne diagnostiske algoritmer for å identifisere tilfeller blitt mer vanlig innen medisinsk forskning (Quigley et al., 1991). Denne metoden er rask og innebærer ingen ekstra kostnader, og har potensiale til å validere sykdommer der samme behandlingsrutiner benyttes universelt i ett område. Bruken av en slik algoritmisk fremgangsmåte på pasientdata kan ekskludere mindre alvorlige tilfeller av villet egenskade som ikke trenger medisinsk behandling. På den andre siden begrenses typiske valideringsmetoder på grunn av kostnadene, og generaliserbarheten er innskrenket ettersom ikke alle medisinske klinikker deltar. Ved å bruke diagnostiske algoritmer kan vi unngå slike begrensninger da metoden er vidtfavnende og kostnadseffektiv.

Vi benyttet en prosedyre for datautvinning som sørget for at kun faktiske nye tilfeller av skade ble beholdt som relevante mulige tilfeller for videre betraktning. For eksempel var en diagnose med skade, i form av kode Soo-T98, et krav i utvelgelsen av relevante tilfeller for videre undersøkelse. Vår tilnærming til datautvinning eliminerer samtidig mulige dobbeltrapporteringer av samme skadetilfelle, skader som var tydelige ulykker eller påført av andre, skader hos små barn eller ikkeaktive innbyggere i Norge, samt skader med et dødelig utfall. En slik tilnærming er svært viktig i studier av tilfeller av villet egenskade når det benyttes administrative data slik som Norsk pasientregister. Denne studien er, etter hva vi kjenner til, den første som presenterer en klar og grundig beskrivelse av prosessen for datautvinning i studier av villet egenskade i registerdata.

Selvsagt avhenger nøyaktigheten av data om både registrerte og justerte tilfeller av villet egenskade av kvaliteten på dataregistreringen utført av klinikerne. I akuttklinikker blir vurderinger av intensjonaliteten til skader ofte ikke prioritert under behandling. Som vist i vår studie ble bare 13533 skadetilfeller, rundt 2250 hvert år, registrert som villet egenskade, det vil si med en diagnose med X6n, X6 eller Y87, noe som tyder på en klar underrapportering av villet egenskade i pasientregisteret. Dette var spesielt tydelig i de første årene med innrapportering til registeret, samt hos tilfeller som involverte pasienter med høy alder. Sammenlignet med registrerte tilfeller av villet egenskade fanget det foreslåtte kodingssystemet opp relativt flere tilfeller av villet egenskade i den tidligste studieperioden og tilfeller som involverte menn og eldre personer. Til sammen ble antallet tilfeller av villet egenskade nesten tredoblet når de sannsynlige tilfellene identifisert av kodingssystemet ble inkludert, fra rundt 2250 til 6400 hvert år - et antall som er svært sammenlignbart med det ofte siterte antallet i Norge (Kopiar et al., 2005), selv om vi ikke kunne lokalisere en vitenskapelig kilde for dette estimatet.

Enda forskning på villet egenskade i økende grad har benyttet seg av pasientregistre, er det stor variasion mellom studier når det kommer til metoden de benytter for å identifisere tilfeller av villet egenskade fra sine data. For å identifisere tilfeller av villet egenskade har eksempelvis The National Self-Harm Registry i Irland fått dataene undersøkt i tråd med registerets standardiserte metode for konstatering av tilfeller (Perry et al., 2012); The Multicentre Self-Harm Database i Storbritannia benytter eksperter for å diagnostisere villet egenskade (Hawton et al., 2007); studier fra Sverige benytter vanligvis de registrerte ICD-kodene for villet egenskade (E950-9, X6o-84) og usikre tilfeller (E980-9, Yo1-34) for å identifisere tilfeller av villet egenskade fra det svenske pasientregisteret (Runeson et al., 2010). Danmark har på den annen side giennomført en valideringsstudie med bruk av ytre data for å produsere et diagnostisk system for å identifisere mulige tilfeller av villet egenskade fra det nasjonale pasientregisteret (Helweg-Larsen et al., 2006). Dette anbefalte diagnostiske systemet har blitt benyttet i flere studier om villet egenskade i Danmark (Reuter Morthorst et al., 2016; Erlangsen et al., 2015; Madsen et al., 2013) og er svært sammenlignbart med vårt utviklede diagnostiske system.

På tross av at prosedyrene for utvikling av vårt diagnostiske kodingssystem for identifisering av tilfeller av villet egenskade er datadrevet og har bakgrunn i kunnskap om villet egenskade, er det mulig at vårt estimat for antall justerte tilfeller av villet egenskade ikke er det sanne antallet, men kun et steg nærmere sannheten. Det er et klart behov for å utvikle metoder for å fastslå tilfeller av villet egenskade på nasjonale og regionale nivåer som er både praktisk giennomførbare og vitenskapelig valide. Det er også onskelig å giennomføre videre studier for å validere det foreslåtte algoritmiske systemet og resultatene presentert i denne studien. Vi planlegger i skrivende stund en slik valideringsstudie giennom å benytte data fra andre kilder i Norge.

\section{Justerte tilfeller av villet egenskade og estimert forekomst i Norge}

Totalt ble 38433 tilfeller av villet egenskade, rundt 6400 tilfeller fra 5130 unike personer hvert år, identifisert giennom det foreslåtte diagnostiske kodingssystemet i løpet av den 6 år lange studieperioden. I alt $60,5 \%$ av disse tilfellene var blant kvinner, 48,6\% var blant personer under 35 år, 57,8\% fikk en komorbid psykiatrisk diagnose og $88,9 \%$ involverte forgiftning med medikamenter eller andre stoffer, mens 13,7\% 
involverte skader på kroppen. Den estimerte årlige insidensraten var 121,0 (95\% KI: 113,4-128,2), 133,4 (95\% KI: 121,7-145,1) og 108,6 (95\% KI: 100,6-116,6) per 100 ooo mennesker for henholdsvis totalen, kvinner og menn over 10 år i Norge.

Villet egenskade som krever behandling i spesialisthelsetjenesten representerer relativt alvorlige tilfeller der forgiftning med medikamenter er vanligst. Vårt funn at $83,3 \%$ av de justerte tilfellene av villet egenskade involverte forgiftning med medikamenter er i tråd med resultater fra nasionale data fra Sverige $(83,8 \%$ av all selvskading registrert med E950-9, E980-9, X6o-84 eller Yo1-34) (Runeson et al., 2010), Irland (legemiddeloverdose var eneste metode i 68\% av tilfellene, 75\% blant kvinner og 59\% blant menn) (Perry et al., 2012) og Danmark (Reuter Morthorst et al., 2016).

Vårt funn som viser en svært høy forekomst av villet egenskade blant unge jenter og en ratio mellom kvinner og menn over 6:1 blant ungdom mellom 13 og 16 år samsvarer også med tidligere studier som rapporterer at villet egenskade var rundt 5 ganger så vanlig blant jenter sammenlignet med gutter i alderen 12-15 år (Hawton et al., 2012). Denne ubalansen mellom kiønnene er mye større enn den som rapporteres i spørreundersøkelser i de fleste land (Madge et al., 2008), noe som indikerer at relativt flere kvinner enn menn med villet egenskade mottar behandling i spesialisthelsetjenesten. Antallet sammenlignbare studier av sykehusbehandlet villet egenskade blant eldre er begrenset, men forekomsten av villet egenskade blant eldre i vår studie var betydelig høyere enn tidligere rapporterte rater (Reuter Morthorst et al., 2016).

Den høye forekomsten av psykiatrisk komorbiditet blant personer med villet egenskade har blitt godt dokumentert i både kliniske populasjoner og i befolkningen generelt (Hawton et al., 2013). Våre resultater viser at så mange som $57,8 \%$ av de justerte tilfellene av villet egenskade hadde en psykiatrisk diagnose. Selv om dette er noe lavere enn en komorbiditet på over $80 \%$ som ble rapportert i en systematisk litteraturgiennomgang av studier som giennomførte vurderinger av psykiatrisk komorbiditet blant pasienter med villet egenskade er dette estimatet i tråd med studier basert på pasientregistre (Runeson et al., 2010; Perry et al., 2012; HelwegLarsen et al., 2006).

Våre estimerte årlige insidensrater på 108,6/100 ooo for menn og 133,4/100 ooo for kvinner er sammenlignbare med insidensratene rapportert i Danmark (86,9/100 ooo for menn og 130,7/100 ooo for kvinner) som også ble estimert basert på et tilsvarende diagnostisk algoritmisk system (Reuter Morthorst et al., 2016). Disse ratene er derimot betraktelig lavere enn de rapporterte insidensratene i Irland (årlig rate for totalen, menn og kvinner var henholdsvis 198, 173 og 224 per 100 ooo) (Perry et al., 2012). Det er vanskelig å si om denne forskjellen skyldes de betydelige metodologiske forskjellene i de ulike studiene eller hvorvidt den representerer faktiske forskjeller i forekomsten av villet egenskade mellom de ulike populasjonene. Uansett ser vi at dataene fra Irland dekker relativt flere tilfeller som involverer skader på ulike deler av kroppen (Perry et al., 2012).

\section{Studiens begrensninger og styrker}

Resultatene fra denne studien må tolkes i lys av noen metodiske styrker og begrensninger. Studien begrenser seg til tilfeller av villet egenskade behandlet på sykehus. Et ukjent antall tilfeller av villet egenskade mottar ikke medisinsk behandling (Geulayov et al.,, 2018) og resultater fra denne studien kan selvsagt ikke generaliseres til disse. Det gielder også våre estimater av forekomst av villet egenskade som ikke må forstås som et estimat av det samlete antall tilfeller av villet egenskade i Norge. Vårt estimat kan også være påvirket av en intern underestimering ved sykehusene på grunn av feil og mangler i rapporteringsprosessen. Til tross for vårt systematiske arbeid med datautvinning og utvikling var det antageligvis skadetilfeller som i realiteten var tilfeller av villet egenskade, men som manglet tilleggsinformasjon slik som diagnoser av X6n eller psykiske lidelser og dermed ikke ble fanget opp av vårt foreslåtte kodingssystem. Samtidig kan vi ikke utelukke at skadetilfeller som ikke dreide seg om villet egenskade ble inkludert i våre estimater. Med sine iboende styrker og svakheter er denne studien, så vidt vi vet, den første til å utvikle en datadrevet diagnostisk algoritme for koding som kan benyttes for å identifisere valide tilfeller av villet egenskade fra et administrativt pasientregister.

\section{Noen implikasjoner av funnene}

I mangel på informasjon om villet egenskade på et populasjonsnivå, både i Norge og i andre land, kan bruk av en datadrevet diagnostisk algoritme som den vi har utviklet i denne studien betraktelig øke utnyttelsen av pasientdata og intensivere forskningen på dette feltet.

Villet egenskade er en hyppig årsak til akuttbehandling og har store psykiske, sosiale og økonomiske ringvirkninger i samfunnet. Selv om vi mangler et etablert system for kontinuerlig monitorering av villet egenskade i befolkningen, kan medisinske registre fra sykehus og akuttbehandling utvilsomt utgiøre en verdifull kilde for monitorering av befolkningen og for forskning som kan informere videre forebygging. Den kraftige underrapporteringen av villet egenskade i pasientregistre, slik som vi ser i NPR, indikerer likevel at standardisering av rapporteringsprosessen er nødvendig for å forbedre kvaliteten på dataene. Selv om vårt diagnostiske kodingssystem må valideres videre giennom å benytte ytre informasion, utgiør metoden et grunnlag for å benytte denne omfattende og rike datakilden i NPR for å gi okte kunnskaper om personer som behandles for villet egenskade. Dette gir et grunnlag for verdifull informasion til dem som driver akuttbehandlingen og arbeidet med å følge opp pasientene etter akuttfasen. 


\section{Merknad}

Data fra Norsk pasientregister har blitt benyttet i denne studien. Forfatterne er alene ansvarlige for fortolkningen og rapporteringen av disse dataene, og godkjenning av fortolkning og rapportering har ikke blitt gitt av NPR.

\section{Finansiering}

Studien er støttet av Norges Forskningsråd https://www.forskningsradet.no/en/ (Prosjektnummer.: 260453/H10, PI: PQ).

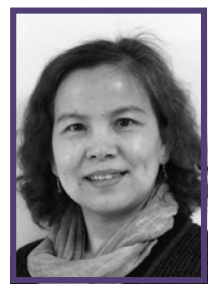

PING QIN er dr.med., professor, spesialist i psykiatrisk epidemiologi og suicidologi ved Nasjonalt senter for selvmordsforskning og -forebygging, Institutt for klinisk medisin, Universitetet i Oslo.

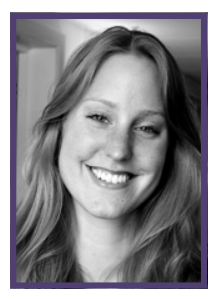

LISA VICTORIA BURRELL er doktorgradsstipendiat i gruppen for registerforskning på selvmord og villet egenskade ved NSSF, Institutt for klinisk medisin, Universitetet i Oslo. Hun har en mastergrad i kognitiv nevropsykologi fra Psykologisk institutt ved Universitetet i Oslo.

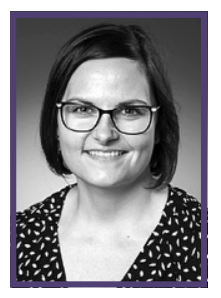

ANNE SELJENES BØE er doktorgradsstipendiat i gruppen for registerforskning på selvmord og villet egenskade ved NSSF, institutt for klinisk medisin, Universitetet i Oslo. Hun har en mastergrad i Læring - hjerne, atferd og omgivelser fra Norges teknisk-naturvitenskapelige universitet.

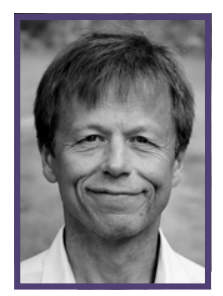

LARS MEHLUM er dr.med., professor i psykiatri og suicidologi, senterleder ved Nasjonalt senter for selvmordsforskning og -forebygging, Institutt for klinisk medisin, Universitetet i Oslo.

\section{REFERANSER}

Deka, R., Bryan, C. I., LaFleur, I., Oderda, G., Atherton, A., \& Stevens V. (2018). Benzodiazepines, Health Care Utilization, and Suicidal Behavior in Veterans With Posttraumatic Stress Disorder. The Iournal of Clinical Psychiatry,79(6).

Direktoratet for e-helse. (2019). ICD-10: Den internasjonale statistiske klassifikasionen av sykdommer og beslektede helseproblemer 2018. Oslo: Direktoratet for e-helse.

Erlangsen, A., Lind, B. D., Stuart, E. A., Qin, P., Stenager, E., Larsen, K. I., .. Nordentoft, M. (2015). Short-term and long-term effects of psychosocial therapy for people after deliberate self-harm: A register-based, nationwide multicentre study using propensity score matching. Lancet Psychiatry, 2(1), 49-58.

Erlangsen, A., Qin, P., \& Mittendorfer-Rutz, E. (2018). Studies of Suicidal Behavior Using National Registers: An Adventure Without Boundaries?. Crisis, 39(3), 153-158.

Geulayov, G., Casey, D., McDonald, K. C., Foster, P., Pritchard, K., Wells, C., ... Hawton, K. (2018). Incidence of suicide, hospital-presenting non-fatal self-harm, and community-occurring non-fatal self-harm in adolescents in England (the iceberg model of self-harm): A retrospective study. Lancet Psychiatry, 5(2), 167-174.

Hawton, K., Bergen, H., Casey, D., Simkin, S., Palmer, B., Cooper, I., . . . Owens, D. (2007). Self-harm in England: a tale of three cities. Multicentre study of self-harm. Soc Psychiatry Psychiatr Epidemiol, 42(7), 513-521.

Hawton, K., Saunders, K. E., \& O'Connor, R. C. (2012). Self-harm and suicide in adolescents. Lancet, 379(9834), 2373-2382.

Hawton, K., Saunders, K., Topiwala, A., \& Haw, C. (2013). Psychiatric disorders in patients presenting to hospital following self-harm: A systematic review. I Affect Disord, 151(3), 821-830.

Helsedirektoratet. (2019). Innhold og kvalitet i NPR. Hentet fra https://www. helsedirektoratet.no/tema/statistikk-registre-og-rapporter/helsedata-og-helseregistre/norsk-pasientregister-npr/innhold-og-kvalitet-i-npr.

Helweg-Larsen, K., Kjoller, M., Iuel, K., Sundaram, V., Laursen, B., Kruse, M., Nørlev, I., \& Davidsen, M. (2006). Selvmord i Danmark: Markant fald i selvmord, men stigende antal selvmordsforsøg - Hvorfor? København: Statens Institut for Folkesundhed.

Kapur, N., Steeg, S., Turnbull, P., Webb, R., Bergen, H., Hawton, K., . . Cooper, I. (2015). Hospital management of suicidal behaviour and subsequent mortality: A prospective cohort study. The Lancet Psychiatry. 2(9), 809-816.

Kopiar, B., Dieserud, G., \& Wiik, I. (2005). Selvpåførte forgiftninger behandlet i sykehus. Tidsskr Nor Laegeforen, 125(13-14), 1798.

Madge, N., Hewitt, A., Hawton, K., Wilde, E. I. d., Corcoran, P., Fekete, S., ... Ystgaard, M. (2008). Deliberate self-harm within an international community sample of young people: comparative findings from the Child \& Adolescent Self-harm in Europe (CASE) Study. I Child Psychol Psychiatry, 49(6), 667-677.

Madsen, T., Agerbo, E., Mortensen, P. B., \& Nordentoft, M. (2013). Deliberate self-harm before psychiatric admission and risk of suicide: survival in a Danish national cohort. Soc Psychiatry Psychiatr Epidemiol, 48(9), 1481-1489.

Muehlenkamp, I. I., Claes, L., Havertape, L., \& Plener, P. L. (2012). International prevalence of adolescent non-suicidal self-injury and deliberate self-harm. Child Adolesc Psychiatry Ment Health, 6(1), 10.

Perry, I. I., Corcoran, P., Fitzgerald, A. P., Keeley, H. S., Reulbach, U., \& Arensman, E. (2012). The incidence and repetition of hospital-treated deliberate self harm: Findings from the world's first national registry. PloS one, $7(2)$, e31663.

Qin, P. \& Mehlum, L. (2020). Deliberate self-harm: Case identification and incidence estimate upon data from national patient registry. PloS one, 15(4), e0231885. 
Qin, P., Mortensen, P. B., \& Pedersen, C. B. (2009). Frequent change of residence and risk of attempted and completed suicide among children and adolescents. Arch Gen Psychiatry, 66(6), 628-632.

Quigley, M. A., Chandramohan, D., \& Rodrigues, L. C. (1991). Diagnostic accuracy of physician review, expert algorithms and data-derived algorit$\mathrm{hms}$ in adult verbal autopsies. Int I Epidemiol, 28(6), 1081-1087.

Reuter Morthorst, B., Soegaard, B., Nordentoft, M., \& Erlangsen, A. (2016). Incidence Rates of Deliberate Self-Harm in Denmark 1994-2011: A Nationwide Register Study. Crisis, 37(4), 256-264.

Runeson, B., Tidemalm, D., Dahlin, M., Lichtenstein, P., \& Långström, N. (2010). Method of attempted suicide as predictor of subsequent successful suicide: national long term cohort study. BMI. 341, C3222.

Statistisk sentralbyrå (2020a). Befolkning. Hentet fra https://www.ssb.no/ data-til-forskning/utlan-av-data-til-forskere/variabellister/befolkning.

Statistisk sentralbyrå. (2020b). FD-Trygd. Hentet fra https://www.ssb.no/ data-til-forskning/utlan-av-data-til-forskere/variabellister/fd-trygd.

Statistisk sentralbyrå (n.d.). Befolkning. Hentet fra https://www.ssb.no/ statbank/list/folkemengde.

World Health Organization. (2014). Preventing suicide: a global imperative: World Health Organization. 